\title{
The Role of Free Living Nematode Population in the Organic Matter Recycling
}

\author{
Saroj Yadav*, Jaydeep Patil and R. S. Kanwar \\ Department of Nematology, College of Agriculture, CCS HAU Hisar, Haryana, India \\ *Corresponding author
}

\section{Keywords}

Organic matter recycling, mineralization,

bacterivorous,

omnivorous, and

predatory nematodes etc.

Article Info

Accepted:

20 May 2018

Available Online:

10 June 2018

\begin{abstract}
A B S T R A C T
Organic matter as truly the key to soil fertility and health. Free-living nematodes play

important roles in soil nutrient cycling. Nematode excretion may have contributed soluble nitrogen in soil. Nematodes have more $\mathrm{C}: \mathrm{N}$ ratio and lower $\mathrm{N}$ content as compare with the bacteria $\mathrm{C}: \mathrm{N}$ ratio they consume. Growth efficiency of nematodes is smaller than those of the bacteria. Nitrogen mineralization, abundance of many free-living nematodes populations in soil mainly bacterivorous, omnivorous, and predatory nematodes. They were also found to correlate with concentrations of many other soil nutrients in a fallow land. Bacterial grazers protozoa and bacterivorous nematodes contributed more of the nitrogen mineralized by fauna, which was as compared with the mineralized by microbes. In the soil, nematodes have a function to decrease the remains of larger animals and plant tissues. Under field conditions, bacterivorous and predatory nematodes are contributed directly and indirectly about for the nitrogen mineralization in conventional and integrated farming systems, respectively. Predatory nematodes also regulate nitrogen mineralization by feeding on microbial grazing nematodes, a conduit by which resources pass from bottom to top trophic levels.
\end{abstract}

\section{Introduction}

Soil health is the natural dynamic body having the capacity to function within ecosystem boundaries to sustain biological productivity, maintain environmental quality and promote plant and animal health. Fertile soil should be able to support life processes such as plant anchorage and nutrient supply, retain optimal water and soil properties, support soil food webs, recycle nutrients, maintain microbial diversity, and remediate pollutants, and sequester heavy metals. Nematodes or roundworms are unsegmented with tapered ends typically, head, and a tail with a well-developed central nervous and fertility system with a complete digestive system, so they are considered the most primitive animal.

They are microscopic that's why it fit in most soil pores and soil aggregates. It is classified in the animal phylum Nemata and is best known for causing infectious disease in plants and animals, but they also play an important role in soil and crop ecology. On the basis of their feeding habits, nematodes are known as plant feeders, bacterial feeders, fungal 
feeders, algal feeders, animal predators, and omnivores (Yeates et al., 1993). All these types of nematodes co-occur in soil. Nematologists assert that nematode disease suppression also should be a function of soil health.

Nematodes are aquatic organism; it requires adequate soil moisture to move in the soil. Most of the species are responsible for cause's economic losses but far less is known about the majority of the nematode community that plays beneficial roles in soil. Many beneficial nematodes serve as biological pest control agents in managed systems and others regulate the natural ecosystem and soil nutrient cycling. Few feed on the plants and algae (first trophic level); others are grazers that feed on bacteria and fungi (second trophic level); and some feed on other nematodes (higher trophic levels). A different nematodes function at several trophic levels of the soil food web. Nematodes are most abundant in the surface soil horizon.

When farmers are adding organic matters to the soil, organic residues must be decomposed to release nutrients for plant to uptake. Decomposition of organic matter in a soil can be divided into two channels, a faster bacterial channel and a slower fungal-based channel. Soil ecosystem types and nutrient forms e.g., Carbon to Nitrogen ratios or $\mathrm{C}$ : $\mathrm{N}$ ratios determine the predominant decomposition channels (Ingham et al., 1985). Moreover bacteria and fungi are the primary decomposers in the soil food web, these microbes also can immobilize inorganic nutrients in the soil (Ingham et al., 1985), making nutrients unavailable for plants to uptake.

Nematode metabolites may stimulate specific bacterial growth by releasing growth-limiting nutrients such as $\mathrm{N}$ and vitamins. However, overgrazing of bacterial or fungal populations by nematodes can result in a reduction of the overall activity of these decomposers. Fortunately, in the hierarchy of the soil food web, generalist predators such as the omnivorous and predatory nematodes) prey on these bacterivorous and fungivorous nematodes, improving nutrient cycling and allowing more nutrients to be released (Yeates and Wardle, 1996). Therefore, freeliving nematodes play important roles in soil nutrient cycling. Nematode excretion may contribute up to $19 \%$ of soluble $\mathrm{N}$ in soil (Neher, 2001). This is due to the fact that nematodes $\mathrm{C}$ : $\mathrm{N}$ ratio of $8-12$ have a lower $\mathrm{N}$ content than the bacteria $\mathrm{C}: \mathrm{N}$ ratio of 3-4 and they consume (Wasilewska and Bienkowski, 1985). In addition, the growth efficiency of nematodes $(<25 \%)$ is smaller than those of the bacteria (> 30\%) (Hunt et al., 1987).

Therefore, nematodes excrete a majority of both the assimilated Carbon and Nitrogen that they consumed from the bacteria. In the other hand, bacteria respire most of the assimilated Carbon, but immobilized most of the assimilated Nitrogen. Therefore the contribution made by nematodes to nitrogen mineralization making nitrogen available to plants is relatively high compared to bacteria in soil ecosystems.

Besides contributing to $\mathrm{N}$ mineralization, the abundance of many free-living nematodes, especially bacterivorous, omnivorous, and predatory nematodes, also were found to correlate with concentrations of many other soil nutrients in a fallow field (Wang et al., 2004), suggesting the possibility of nematodes mineralizing many other soil nutrients. Adding organic amendments to the soil, growing cover crops as green manure, covering soil with organic mulch, and practicing conservation tillage are various methods to enhance population densities of beneficial free-living nematodes in the soil. 
The categorization of trophic groups of nematodes

\section{Based on feeding habits, nematodes, which are recognized as the major}

Consumer group in the soil can be divided into five categories, namely:

Plant-feeding nematodes (root-feeding nematodes; phytophagous; plant parasites)

Fungal-feeding nematodes (fungivorous; mycophages)

Bacterial-feeding nematodes (microbivorous; bacterivorous)

Predatory nematodes

Omnivorous nematodes (Zunke and Perry 1997; Norton and Niblack 1991; and Ingham 1996)

Plant parasitic nematodes which feed on higher plant usually have stylets to suck the nutrients from the plants which have a wide diversity of size and structure. These groups of nematodes have an ability to cause plant disease and reduce crop yield (Yeates 1970 and Ingham, 1996).

Fungal-feeding nematodes, which feed on fungal mycelium, hyphae, conidia, including plant pathogenic fungi, have "protusible hollow stylets". For example, Aphelenchus sp., Aphelenchoides hamatus (Zunke \& Perry 1997; Ingham 1996)

Bacterial-feeding nematodes which feed on bacteria and other micro flora have "a simple, open and unarmed stoma in the form of cylindrical or triangular tube, terminating in teeth valve-like apparatus" (Nicholas 1975 in Ingham 1996). For example, Acrobeles spp. which are mainly live in sandy soil,
Bunonema spp. which is found in moss, decaying vegetable matter, cow dung and rotting wood of bark beetle tunnels, Rhabditis sp., Acrobeliodes tricornis, Caenorhabditis elegans, Panagrolaimus subelongatus (Zunke \& Perry 1997; Laakso \& Setala 1999).

Predatory nematodes that feed on other nematodes have a monochous type of stylet or a wide cup-shaped cuticular line stoma armed with powerful teeth (Nicholas 1975 in Ingham, 1996) for instance, Mononchus spp., Parazercon radiatus. Omnivorous nematodes feed on algae, bacteria, fungi, protozoas, rotiferas, tardigrads, etc. for instance, Dorylaimus spp., Lysigamasus lapponicus which feed on microarthropods (Laakso \& Setala, 1999).

\section{Ecological importance of nematodes}

The nematodes species live every habitat such as prairies, woodland, cultivated fields, etc. The abundance of nematodes depend on many factors, viz., soil texture, soil structure, air and soil temperature, rainfall, soil moisture, evaporation, soil conductivity, $\mathrm{pH}$, plant material and topography (Wallace, 1973). Nematodes can be abundant in areas with a particular condition. In an experiment, Neher and Blair (1997) found that the number of nematodes increases in habitats with least moisture, and the number of nematodes decreased considerably in the aquatic areas.

Temperature also affects the abundance of nematodes in the soil. The change of moisture and temperature may cause preventing the nematodes from persisting in the soil. Climatic factors mainly, Moisture and temperature become fluctuated due to the cultivation and as a result it changes soil structure. Consequently, the diversity of nematodes in the agricultural ecosystem is lower than in natural ecosystem (Norton and Niblack, 1991). 
Nematodes biomass is also responsible for the influences with the soil porosity. The total soil biomass was greater in sandy soils $(0.6 \%)$ of biomass carbon than in loamy soils $(0.3 \%)$ or clay soils $(0.1 \%)$ lead to the influence of nematode (Badgett and Griffiths, 1997). This can occur because of the movement of the nematodes through soil pores. The nematodes can move in the soil more easily and more quickly because they microscopic organism and they may affect the nematodes abundances is the soil depth. There are greatest numbers of nematodes at $5-10 \mathrm{~cm}$ depths and they decrease at $0-2.5 \mathrm{~cm}$ or warmer surface soil (Neher and Blair, 1997). It can see due to the soil profile or different layers in forest litter (Bardgett and Griffiths, 1997). Besides that, some species of nematodes prefer different soil depth (Wallace, 1973)

\section{The role of nematode in the soil}

However, they cannot decompose the organic matter or influence the mechanical and physical of the soil directly (Nielsen, 1967). There are several factors of indirect effects of microbial-feeding nematodes, the modification of the microbial community, accelerated turnover of microbial cells and the inoculation of new substrates. Consequently, bacteria and fungi as primary decomposer have important role of decomposition. Primary decomposition begins with the living plant or with dead plant remains. After the organic matter is decomposed, the amount of organic matter, availability of organic chemicals and the ability of number of microorganism decomposing substrate are reduced considerably.

According to Bardgett and Griffiths (1997), the consumption of microbial feeding nematodes is:

5\%-8\%: organic matter input
5\%-25\%: the bacterial standing crop

4\%-22\%: contribution to total net nitrogen mineralization

10\%: the ecological growth efficiency (production per consumption)

Compared to the five categories of nematodes, microbial-feeding nematodes viz., bacterivorous, fungivorous, and omnivores and plant-feeding nematodes are more important in decomposition and nutrient mineralization than predatory nematodes. It probably leads to the abundance of the nematodes in environment, their high turnover rate, and the strong interactions with soil microbes (Laakso and Setala, 1999). Another reason is that the nematodes' food comes from the microorganisms, microflora, and higher plants in the soil (Nielsen, 1967). In addition, there is significant effect among bacterivorous, fungivorous, and predatory nematodes. Laakso and Setala (1999) found that predatory nematodes could be important regulators of microbial-feeding nematodes, because they can reduce the microbivorous' biomasses. Due to the feeding habits of nematodes are different, they are also have different role in soil food web. Plant-feeding nematodes are usually live in grass fields or other habitats with many types of vegetation (Nielsen, 1967). All the nematodes, plantfeeding nematodes are deleterious to the plant growth, because they can decrease the productivity of the plants with damaging the root systems. There are several controls of plant-feeding nematodes, such as vesiculararbuscular mycorrhizal fungi, nematode trapping fungi, or other fungi and bacteria which can prevent the presence of the nematodes (Ingham, 1996).

Bacterial-feeding nematodes are dominant in forest litter, compost heaps, and agriculture and grassland systems (Ingham 1996; Nielsen 
1967). This group of nematodes usually consumes 106 bacteria per day; as a result net nutrient immobilization can increase whereas nutrient mineralization decreases (Ingham, 1996). The number of bacterivorous can increase with the presence of plant-feeding nematodes which due to the greater distribution of the food source in the soil (Griffiths and Bardgett, 1997).

Fungal-feeding nematodes are dominant in the soil that is dominated by fungi, such as conifer and deciduous forests. The fungivorous can consume the cytoplasm in 10-50 meters of hyphal length per day (Ingham, 1996). Both bacterivorous and fungivorous have more important role in soil food web rather than other types of nematodes. A large percentage of nitrogen is released by this group of nematodes when attacking their prey (Ingham, 1996). Both predatory nematodes and omnivorous nematodes do not give as great contribution as bacterial-feeding nematodes and fungifeeding nematodes. However, they also affect the chain of food in the soil. Laakso and Setala found that predatory nematodes could become important regulators for bacterialfeeding nematodes and then can affect the microbial activity. In contrast, omnivorous nematodes did not have strong effect on fungi-feeding nematodes (Laakso and Setala, 1999).

\section{Role of Nematodes in Soil Nutrient Cycling}

Nematodes play an important role in essential process of the soil organic matter decomposition. The direct contribution of nematodes to nitrogen mineralization and distribution of biomass within plants and detritus and organic residues must decompose to release nutrients for plant uptake. Decomposition of organic matter in a soil food web can be divided into two energy channels, a faster bacterial channel and a slower fungal-based channel. Soil ecosystem types and nutrient forms e.g., $\mathrm{C}$ : $\mathrm{N}$ ratios determine the predominant decomposition channels. (Ferris et al., 2003 and Ingham et al., 1985) Although bacteria and fungi are the primary decomposers in the soil food web, these microbes also can immobilize inorganic nutrients in the soil (Ingham et al., 1985). These decomposition channels, when the bacterivorous and fungivorous nematodes graze on these microbes, they give off $\mathrm{CO}_{2}$ and $\mathrm{NH}_{4}{ }^{+}$and other nitrogenous compounds, affecting carbon and nitrogen mineralization directly (Ingham et al., 1985)). Indirectly, nematodes can disseminate microbial propagules throughout the soil (Freckman, 1988), which advances the colonization of substrates and mineralization of nutrients. Nematode metabolites may also stimulate specific bacterial growth by releasing growthlimiting nutrients such as $\mathrm{N}$ and vitamins. However, overgrazing of bacterial or fungal populations by nematodes can result in a reduction of the overall activity of these decomposers. Fortunately, in the hierarchy of the soil food web, generalist predators prey on these bacterivorous and fungivorous nematodes, improving nutrient cycling and allowing more nutrients to be released (Yeates and Wardle, 1996).

Therefore, nematodes play important roles in soil nutrient recycling. Nematode excretion may contribute up to $19 \%$ of soluble $\mathrm{N}$ in soil (Neher, 2001). This is due to the fact that nematodes (C: $\mathrm{N}$ ratio of $8-12$ ) have a lower $\mathrm{N}$ content than the bacteria (C: $\mathrm{N}$ ratio of 3-4) they consume (Wasilewska and Bienkowski, 1985). In addition, the growth efficiency of nematodes $(<25 \%)$ is smaller than those of the bacteria (> 30\%) (Hunt et al., 1987). Therefore, nematodes excrete a majority of both the assimilated $\mathrm{C}$ and $\mathrm{N}$ that they consumed from the bacteria. Bacteria, on the other hand, usually respire most of the assimilated $\mathrm{C}$, but immobilized most of the 
assimilated $\mathrm{N}$. Therefore the contribution made by nematodes to $\mathrm{N}$ mineralization is relatively high compared to bacteria in soil ecosystems. Besides contributing to $\mathrm{N}$ mineralization, the abundance of many freeliving nematodes, especially bacterivorous, omnivorous, and predatory nematodes, also were found to correlate with concentrations of many other soil nutrients in a fallow field (Wang et al., 2004), suggesting the possibility of nematodes mineralizing many other soil nutrients.

More clear-cut relationships between nematodes and soil nutrients were observed in a field that had been fallow for 1.5 years compared to a recently cultivated field (Wang et al., 2004). The abundance of many bacterivorous genera followed predators and omnivores and correlated significantly $(P<$ $0.10)$ with most soil nutrient concentrations. However, few significant correlations occurred with genera in fungivorous and herbivore groups.

\section{Role of Nematodes in Soil Health}

The direct contribution of nematodes to nitrogen mineralization and distribution of biomass within plants has been demonstrated in controlled experiments. In laboratory experiment studied about the more nitrogen is available in the ammonium form when bacterivorous and fungivorous nematodes are present than when they are absent (Trofymow and Coleman, 1982). Nitrogen mineralized through microbial grazing is available subsequently to plants (Seastedt et al., 1988; Sohlenius et al., 1988) and has been demonstrated to affect biomass allocation in plants. In a microcosm experiment with buffalo grass (Bouteloua gracilis), Ingham et al., (1985) demonstrated that plant shoots grow larger in soils with bacteria, fungi, and their respective grazers than in soils with less complex soil food webs. Root biomass may also increase in the presence of microbialgrazing nematodes. Under field conditions, bacterivorous and predatory nematodes are estimated to contribute (directly and indirectly) about $8 \%$ to $19 \%$ of nitrogen mineralization in conventional and integrated farming systems, respectively (Beare, 1997). Nematodes contribute to nitrogen mineralization indirectly by grazing on decomposer microbes, excreting ammonium, and immobilizing nitrogen in live biomass (Beare, 1997; Ferris et al., 1998; Ingham et al., 1985).

Predatory nematodes also regulate nitrogen mineralization by feeding on microbial grazing nematodes, a conduit by which resources pass from bottom to top trophic levels (Wardle and Yeates, 1993). Although plants depend on nitrogen for their survival and growth, ecological disruptions such as cultivation or additions of mineral fertilizer increase nitrogen availability, sometimes in excess of, or asynchronous with, plant needs. Increased availability of nitrate and ammonium is associated inversely with succession maturity of nematode communities in cultivated mineral soils for agricultural purposes (Neher, 2001).

The rate of $\mathrm{N}$ mineralization per nematode may increase during an early adaptation phase as nematodes adjust to conditions in sand columns and decline during a later resource limitation phase. Smaller nematodes have higher mineralization rates per unit weight, related to their higher metabolic rates. However, the $\mathrm{N}$-mineralization rate per individual was independent of body weight. Nitrogen mineralization rates will change with temperature and that the relationship with temperature will mirror that of the metabolic rates for these nematodes (Ferris et al., 1995). The respiration rate reflects the integral metabolic activity of an individual nematode. The temperature relationships of 
developmental rates of nematodes do not necessarily mirror those of respiration rates (Ferris et al., 1995, 1996a; Venette and Ferris, 1997). Therefore the coefficients for estimating the $\mathrm{N}$-mineralization potential of species of bacterial-feeding nematodes would appropriately be applied to actual nematode counts to provide an estimate of the $\mathrm{N}$ mineralization potential of the bacterialfeeding nematode community in a given soil. Relative population development rates across a range of temperatures for these nematode species using coefficients provided by Venette and Ferris, 1997.

Soil is a natural dynamic body and it is network of consumer resource interactions among different functional groups of soil organisms which occur in the soil agroecosystem. There are several number of organisms contribute in this web, such as protozoa, nematodes, collembola, mites, insect larvae, earthworms, bacteria, and fungi. Nematodes which are have a great number and live freely in the soil food web in decomposing soil organic matter and mineralizing nutrients. Based on the feeding habits, there are five categories of nematodes, namely plant-feeding nematodes, fungalfeeding nematodes, bacterial-feeding nematodes, predatory nematodes, and omnivorous nematodes. Among all categories, bacterial feeding nematodes and fungal nematodes have more important role of decomposing and mineralizing than other types of nematodes, and plant-feeding nematodes give negative effect on plant growth.

\section{Acknowledgements}

We thanks to Chaudhary Charan singh Haryana Agriculture University, Hisar and Head Department of Nematology, for their valuable suggestions during the writing the review article.

\section{Authors' contributions}

JP prepared the review article. SY and AK they revise the manuscript and JP has been incorporated all the suggestion. Both authors read and approved the final manuscript.

\section{References}

Anderson, R.V., Coleman, D C., Cole, C.V., Elliott, E.T., McClellan, J.F., 1979. The use of soil microcosms in evaluating bacteriophagic nematode responses to other organisms and effects on nutrient cycling. Int. J. Env. Stud. 13, 175-182.

Bardgett, R.D., Griffiths, B.S. 1997. Ecology and biology of soil protozoa, nematodes, and microarthropods. In Modern soil microbiology. Edited by Jan Dirk van Elsas, Jack T.Trevor, and Elizabeth M.H.Wellington, Marcel Dekker, Inc, New York.

Bardgett, R.D., Griffiths, B.S. 1997. Interactions between microbe-feeding invertebrates and soil microorganisms. In Modern soil microbiology. Edited by Jan Dirk van Elsas, Jack T.Trevor, and Elizabeth M.H.Wellington, Marcel Dekker, Inc, New York.

Beare, M. H. 1997. Fungal and bacterial pathways of organic matter decomposition and nitrogen mineralization in arable soil. Pp. 37-70 in L. Brussaard and R. Ferrera-Cerrato, eds. Soil ecology in sustainable agricultural systems. Boca Raton, FL: Lewis

Benckiser, G. 1997. Fauna in soil ecosystems. Edited by Gero Benckiser. Marcel Dekker, Inc., New York.

Bloem, J., de Ruiter, P., Bouwman, L. 1997. Soil food webs and nutrient cycling in agroecosystems. In Modern soil microbiology. Edited by Jan Dirk van Elsas, Jack T.Trevor, and Elizabeth 
M.H.Wellington, Marcel Dekker, Inc, New York.

De Ruiter, P., Neutel, A.M., Moore, J.C. 1997. Fauna in soil ecosystems. Edited by Gero Benckiser. Marcel Dekker Inc., New York.

Dropkin, V.H. 1980. Introduction to plant nematology. John wiley \& sons, Inc., Canada.

Ferris, H., Matute, M. M. 2003. Structural and functional succession in the nematode fauna of a soil food web. Appl. Soil Ecol. 23, 93-110.

Ferris, H., Venette, R. C., and Lau, S. S. 1997. Population energetics of bacterial-feeding nematodes: Carbon and nitrogen budgets. Soil Biol. Biochem. 29, 1183-1194.

Ferris, H., Venette, R. C., Lau, S. S. 1996. Dynamics of nematode communities in tomatoes grown in conventional and organic farming systems, and their impact on soil fertility. Appl. Soil Ecol. 3, 161-175.

Freckman, D. W. 1988. Bacterivorous nematodes and organic-matter decomposition. Agr. Ecosyst. Environ. 24, 195-217.

Griffiths, B.S., Bardgett. 1997. Interactions between microbe-feeding invertebrates and soil microorganisms. In Modern soil microbiology. Edited by Jan Dirk van Elsas, Jack T.Trevor, and Elizabeth M.H.Wellington, Marcel Dekker, Inc, New York.

Hunt, H. W., Coleman, D. C., Ingham, E. R., Elliott, E. T., Moore, J. C., Rose, S. L., Reid, C. P. P., Morley, C. R. 1987. The detrital foodweb in a shortgrass prairie. Biol. Fertil. Soils 3, 57-68.

Ingham, E. The soil foodweb: it's importance in ecosystem health (www.page). [Cited on 19 March 2000]. Available from www.rain.org/ sals/ingham.html.

Ingham, Elaine. 1996. The Soil Foodweb: It's Importance in Ecosystem Health. $13 \mathrm{p}$
Ingham, R. E., Trofymow, J. A., Ingham, E. R., Coleman, D. C. 1985. Interactions of bacteria, fungi, and their nematode grazers: Effects on nutrient cycling and plant growth. Ecol. Monogr. 55, 119140.

Laakso, J., Setala, H. 1999. Population and ecosystem-level effects of predation on microbial-feeding nematodes. Oecologia journal 120, 279-286.

Lee, D. L., Atkinson, H.J. 1977. Physiology of Nematodes. Columbia University Press, New York. 215 p.

Neher, D. A. 2001. Nematode communities as ecological indicatorsof agroecosystem health. Pp. 105-120 in S. R. Gliessman, ed. Agroecosystem sustainability: Developing practical strategies. BocaRaton, FL: CRC/Lewis Press.

Neher, D., Blair, J. 1997. The soil ecosystem: lessons from the extremes. [www.page], a summary of the 1997 SES meeting [cited on 20 March 2000]. Available from WWW. Wcsu.ctstateu.edu/ WAGENERS/1997. html

Nielsen, C.O. 1967. Soil Biology: nematoda. Edited by A.Burges and F. Raw. Academic Press, Inc., New York.

Norton, D.C., Niblack, T.L. 1991. Biology and ecology of nematodes: in manual of agricultural ecology. Edited by William R. Nickle. Marcel Dekker, Inc., London. NY.

Seastedt, T. R., S. W. James., T. C. Todd. 1988. Interactions among soil invertebrates, microbes, and plant growth in the tallgrass prairie. Agriculture, Ecosystems and Environment 24, 219-228.

Sohlenius, B., H. Persson., Magnusson, C. 1977. Distribution of root and soil nematodes in a young Scots pine stand in central Swe-den. Ecological Bulletins (Stockholm) 25: 340-347. 
Trofymow, J. A., Coleman, D. C. 1982. The role of bacterivorous and fungivorous nematodes in cellulose and chitin decomposition. Pp. 117-138inD. W. Freckman, ed. Nematodes in soil ecosystems. Austin, TX: University of Texas.

Trofymow, J. A., D. C. Coleman. 1982. The role of bacterivorous and fungivorous nematodes in cellulose and chitin decomposition. Pp. 117-138 in D. W. Freckman, ed. Nematodes in soil ecosystems. Austin, TX: University of Texas.

Venette, R.C., Ferris, H. 1997. Thermal constraints to population growth of bacterial-feeding nematodes. Soil Biol. Biochem. 29, 63-74.

Wallace, H.R. 1973. Nematode ecology and plant disease. Edward Arnold Ltd., London

Wang, K.H., R. McSorley., R. N. Gallaher. 2004. Relationships of nematode communities and soil nutrients in cultivated soils. Soil Crop Sci. Soc. Florida Proc. 63, 105-113.
Wasilewska, L., and P. Bienkowski. 1985. Experimental study on the occurrence and activity of soil nematodes in decomposition of plant material. Pedobiologia 28, 41-57.

Wright, D.J., Newall, D.R. 1976. Nitrogen excretion, osmotic and ionic regulation in nematodes. In The Organization of Nematodes. Ed. N A Croll. pp 163-210. Academic Press, New York.

Yeates, G. W. 1970. The diversity of soil nematode faunas. Pedobiologia 10, 104-107.

Yeates, G. W., D. A. Wardle. 1996. Nematodes as predators and prey: relationships to biological control and soil processes. Pedobiologia 40, 43-50.

Yeates, G. W., T. Bongers, R. G. M. DeGoede, D. W. Freckman, S. S. Georgieva. 1993. Feeding habits in soil nematode families and genera-An outline for soil ecologists. J. Nematol. 25,101-313.

Zunke, U., Perry, R.N. 1997. Fauna in soil ecosystems. Edited by Gero Benckiser. Marcel Dekker, Inc., New York.

\section{How to cite this article:}

Saroj Yadav, Jaydeep Patil and Kanwar R. S. 2018. The Role of Free Living Nematode Population in the Organic Matter Recycling. Int.J.Curr.Microbiol.App.Sci. 7(06): 2726-2734. doi: https://doi.org/10.20546/ijcmas.2018.706.321 